\title{
Efficient in vitro plant regeneration from leaf derived callus and genetic fidelity assessment of an endemic medicinal plant of Ranunculus wallichianus Wight \& Arnn using RAPD and ISSR markers
}

Srinivasan P ( $\nabla$ karuppusrini@gmail.com )

St Joseph's College Tiruchirappalli https://orcid.org/0000-0001-6286-8612

\section{David Raja H}

St Joseph's College Tiruchirappalli

\section{Tamilvanan $\mathbf{R}$}

St Joseph's College Tiruchirappalli

\section{Research Article}

Keywords: Regeneration, Ranunculus wallichianus, MS medium, Coconut Water, leaf explants, green nodular callus, RAPD, ISSR markers

Posted Date: May 7th, 2021

DOl: https://doi.org/10.21203/rs.3.rs-432950/v1

License: (9) This work is licensed under a Creative Commons Attribution 4.0 International License. Read Full License 


\section{Abstract}

Ranunculus wallichianus is a medicinally important plant and an endemic species to Western Ghats of South India. An efficient and reliable indirect regeneration protocol system for $R$. wallichianus was developed from leaf explants in the present investigation. Leaf explants were cultured on both fullstrength and half-strength MS (Murashige \& Skoog) medium supplemented with different concentrations (1.0 $\mathrm{mg} \mathrm{L}^{-1}$ to $3.0 \mathrm{mg} \mathrm{L}^{-1}$ ) of 2,4-D and NAA. Among the different concentrations tested, the highest percentage of yellowish green compact nodular callus formation was observed on half-strength MS medium with $2.0 \mathrm{mg} \mathrm{L}^{-1}$ of 2, 4-D. Then, the in vitro raised organogenic callus was cultured on half strength MS medium containing various concentrations $\left(1.0 \mathrm{mg} \mathrm{L}^{-1}\right.$ to $\left.3.0 \mathrm{mg} \mathrm{L}^{-1}\right)$ of BA, KIN and TDZ with $0.5 \mathrm{mg} \mathrm{L}^{-1} \mathrm{NAA}$ and $10 \% \mathrm{CW}$ for in vitro shoot regeneration. The highest percentage of regeneration response (97\%) and maximum number of shoots formation (11.1 \pm 0.13 shoots/culture with $9.2 \pm 0.35$ $\mathrm{cm}$ mean shoot length) were obtained from MS medium containing $2.5 \mathrm{mg} \mathrm{L}^{-1}$ BA with $0.5 \mathrm{mg} \mathrm{L}^{-1} \mathrm{NAA}$ and $10 \% \mathrm{CW}$. The well elongated in vitro raised shoots were rooted in half strength MS medium with 2.5 $\mathrm{mg} \mathrm{L}^{-1}$ IBA $+250 \mathrm{mg} \mathrm{L}^{-1}$ activated charcoal shows high frequency of root formation. The well rooted plantlets were successfully hardened and acclimatized with the survival rate of $94 \%$. Clonal fidelity of in vitro raised plantlets was assessed by using DNA based RAPD and ISSR molecular markers. The total of 56 and 47 monomorphic bands were obtained from RAPD and ISSR markers respectively. This present in vitro propagation protocol system could be an effective for the conservation of $R$. wallichianus with their genetic purity and its further investigations.

\section{Main Text}

Ranunculus wallichianus Wight \& Arnn (Wallich butter cup) is an endemic medicinal plant that belongs to the Ranunculaceae family (Mathew 1996; Kumar 2004). The genus Ranunculus has diverse pharamacological actions. Being an endemic with medicinal worth, $R$. wallichianus has been constantly collected from the wild and conventional propagation through seeds was unsuccessful because of the meagre level of embryo formation. Naturally, the species $R$. wallichianus is propagating through suckers. However, the plant cannot be reproducing their population because of their habitat destruction and seasonal variations. Hence, reliable and reproducible studies need to conservation of $R$. wallichianus. In vitro multiple shoot induction via calli is a promising tool for the establishment and regeneration of a large number of plantlets (Hossain et al. 2003; Anu et al. 2004; Hammerschlag et al. 2006). In vitro propagation of $R$. wallichianus through nodal segments were achieved in our previous study (Srinivasan et al. 2021). Since, no indirect organogenesis of $R$. wallichianus has been reported earlier from leaf explants.

Somaclonal variations may be occurred in in vitro propagated plantlets due to various kinds of biotic and abiotic factors during the in vitro process, particularly in plant regeneration through callus mediated propagation (Breiman et al. 1987). Therefore, evaluation of genetic uniformity of in vitro raised plantlets is compulsory. At the present time, quite a lot of DNA based molecular markers for example Random 
Amplified Polymorphic DNA (RAPD), Simple Sequence Repeats (SSR), Inter-Simple Sequence Repeat (ISSR) and Amplified Fragment Length Polymorphism (AFLP), have been employed to evaluate the genetic stability of a regenerants (Singh et al. 2013; Ebrahimi et al. 2018; El-Mahdy and Youssef 2019; Saeed et al. 2019). Among the various genetic markers, RAPD and ISSR have been predominantly ideal because of their reproducible, reliability, simplicity and cost-effectiveness (Mehrotra et al. 2012). The aim of the present investigation was to develop protocol for large-scale propagation of $R$. wallichianus through indirect organogenesis from leaf explants and to assess the genetic stability of regenerants by using RAPD and ISSR molecular markers.

The leaf explants were collected from the Pampar Shola of Kodaikanal, India and surface sterilized by $1 \%$ $(\mathrm{w} / \mathrm{v})$ Teepol solution and disinfected with $5 \%$ Bavistin for 3 min each. Then, the explants were treated

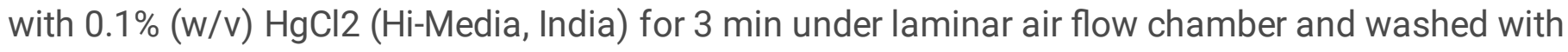
autoclaved double distilled water for 5 min to eliminate the excess of $\mathrm{HgCl}_{2}$. The leaf explants were cultured on MS (Murashige and Skoog 1962) medium containing $30 \mathrm{~g} \mathrm{~L}^{-1}$ sucrose and $8 \mathrm{~g} \mathrm{~L}^{-1}$ agar with 1.0 to $3.0 \mathrm{mg} \mathrm{L}^{-1} 2,4-\mathrm{D}$ and NAA and the $\mathrm{pH}$ was adjusted to 5.7 before autoclaving. The inoculated leaves were incubated at $25 \pm 2{ }^{\circ} \mathrm{C}$ with a $16 \mathrm{~h}$ photoperiod under white cool fluorescent tube light with 50 $\mu \mathrm{Em}^{2} \mathrm{~s}^{-1}$ Photon Flux Density. For multiple shoot regeneration, the $45 \mathrm{~d}$ of well proliferated callus was transferred to the half-strength MS medium containing various concentrations ( $1.0 \mathrm{mg} \mathrm{L}-1$ to $3.0 \mathrm{mg} \mathrm{L}-1$ ) of BA, KIN, TDZ with $0.5 \mathrm{mg} \mathrm{L}^{-1} \mathrm{NAA}$ and $10 \% \mathrm{CW}$. The subcultures were made fifteen days intervals. The number of regenerated shoots and shoot length were recorded after $30 \mathrm{~d}$ of culture.

The in vitro raised shoots (3.0-5.0 cm long) were excised and transferred to half-strength MS medium containing $250 \mathrm{mg} \mathrm{L}^{-1}$ activated charcoal with $0.5-3.0 \mathrm{mg} \mathrm{L}^{-1}$ IBA for in vitro rooting. The percentage of rooting, mean number of roots per shoot and mean root length was recorded after 2 wk of transfer onto the rooting medium. Finally, the in vitro rooted plantlets were acclimatized. The plantlets were placed in the pots containing mixture of Sterilized Red soil, Vermiculite and Vermicompost in the ratio of 1:1:1. The sterilized Coconut husk and dried Mosses were spread on the soil surface of pots to retain the moisture condition. The potted plantlets were equipped with a quarter strength of M.S. liquid medium for a wk and maintain under a cultivation chamber at $25 \pm 2{ }^{\circ} \mathrm{C}$ under white fluorescent tube light ( $\left.50 \mu \mathrm{Em}^{2} \mathrm{~s}^{-1} \mathrm{PFD}\right)$. At end of fourth week, the well adapted plantlets were transferred to pots containing normal soil and maintained under greenhouse and gradually transferred to the field condition.

The $500 \mathrm{mg}$ of leaf sample from each in vitro plantlet was used for the extraction of genomic DNA by Cetyl-Trimethyl Ammonium Bromide (CTAB) method (Doyle and Doyle 1987). The quality and quantity of the DNA isolated was checked using Agarose $(0.8 \%)$ gel electrophoresis stained with Ethidium Bromide $\left(0.5 \mu \mathrm{g} \mathrm{L}^{-1}\right)$ visualized in a UV transilluminator. Preliminary screening was carried out with 15 sets of each RAPD and ISSR primers. PCR amplification reactions were carried out in a PCR thermal cycler (Gene Amp PCR System 9700, Applied Biosystems) using $15 \mu \mathrm{L}$ reaction volume containing $1.5 \mu \mathrm{L}$ of $1.2 \mathrm{x}$ Dream taq Buffer, $2 \mu \mathrm{L}$ Template DNA, $1 \mu \mathrm{L}$ Primer $(10 \mu \mathrm{M}), 1.5 \mu \mathrm{L}$ of dNTPs, $0.2 \mu \mathrm{L}$ Dream Taq Polymerase, $8.8 \mu \mathrm{L}$ of Double Distilled Water. PCR amplification reaction was performed with an initial 
denaturation of DNA at $95^{\circ} \mathrm{C}$ for $5 \mathrm{~min}$, followed by $45 \mathrm{~s}$ denaturation at $94^{\circ} \mathrm{C}, 1 \mathrm{~min}$ annealing at $42^{\circ} \mathrm{C}$ and 90 s extension at $72{ }^{\circ} \mathrm{C}$ followed by 35 repeated cycles and the final extension was 10 min at $72{ }^{\circ} \mathrm{C}$. The amplified PCR products were resolved by $1.2 \%$ agarose gel electrophoresis and the size of the amplicons were estimated by using a 2-log DNA ladder (NEB Inc., USA). The DNA banding patterns were visualized in a UV transilluminator (GeNei, India) and the image was captured under UV light using Gel documentation system (Bio-Rad, USA).

All data were analyzed with SPSS Software package (version 17.0; SPPS INC., Chicago, IL, USA). The mean number of shoots, Shoot length, mean number roots, root length with standard error was calculated after 6 wk. The sample means were measured by using one way ANOVA followed by Duncan's Multiple Range Test (DMRT) at $5 \%$ probability level $(P \leq 0.05)$.

Callus induction was obtained from leaf explants on half strength MS medium fortified with 1 to $3 \mathrm{mg} \mathrm{L}^{-1}$ 2,4-D and NAA. The callus initiation was observed after 7 days of culture (Fig. 1a). Of these various concentrations tested, half-strength MS medium with 2,4-D $2 \mathrm{mg} \mathrm{L}^{-1}$ produce maximum of 92 percentages result with yellowish green compact nodular callus after 6 wk. (Fig 1b). Numerous studies were reported on highest occurrence of callus induction with 2,4-D (Natarajan and Konar 1970; Meynet and Duclos 1990b; Ball et al. 1993; Beruto et al., 1996; Zheng and Konzak 1999; Morini et al. 2000; Pellegrineschi et al. 2004; Xing et al. 2010; Osman et al. 2016; Miri 2020; Wahyuni et al. 2020). In contrast, NAA produce optimum result with 67 percentages of results at $2.5 \mathrm{mg} \mathrm{L}^{-1}$ with friable green callus. Sarkar and Banerjee (2020) developed a friable callus in Solanum erianthum on medium supplemented with NAA alone. While none of the explants were responded on full strength MS medium. A comparison efficiency of hormone indicates that 2,4-D is positively superior to NAA since the response of explants was $92 \%$ in 2,4-D (Fig.1a). As a result, 2,4-D is an ideal for the induction of yellowish green compact nodular organogenic callus from leaf explants of Ranunculus wallichianus.

$45 \mathrm{~d}$ old calli was transferred to half strength MS medium containing various concentrations $\left(1.0 \mathrm{mg} \mathrm{L}^{-1}\right.$ to $3.0 \mathrm{mg} \mathrm{L}^{-1}$ ) of BA, KIN and TDZ with $0.5 \mathrm{mg} \mathrm{L}^{-1} \mathrm{NAA}$ and $10 \% \mathrm{CW}$ were used for in vitro shoot regeneration (Table 1). In our previous report, half-strength MS containing $3 \mathrm{mg} \mathrm{L}^{-1}$ TDZ with $10 \% \mathrm{CW}$ produced more shoot induction than BA and KIN from nodal segments (Srinivasan et al. 2021). However, in the present study the highest regeneration of shoots (97\%) from calli obtained in half-strength MS medium containing $2.5 \mathrm{mg} \mathrm{L}^{-1}$ BA with $0.5 \mathrm{mg} \mathrm{L}^{-1} \mathrm{NAA}$ and 10\% CW (Table 1, Fig 1d, 1e \& 1f). The number of shoots per callus was $11.1 \pm 0.13$ with $9.2 \pm 0.35 \mathrm{~cm}$ shoot length (Table 1). Half strength MS with BA and NAA was more appropriate PGR for regeneration of adventitious shoots from calli of two Ranunuculus species such as R. sceleratus (Dorion et al. 1975) and R. asiaticus (Meynet and Duclos 1990a). Klimek-Chodacka (2020) recently stated the medium combined with BA and NAA (BN medium) was more effective for proliferation of shoots from calli in Nigella damascena L. Alternatively, TDZ 1.5 $\mathrm{mg} \mathrm{L}^{-1}$ and KIN $3 \mathrm{mg} \mathrm{L}^{-1}$ with $0.5 \mathrm{mg} \mathrm{L}^{-1} \mathrm{NAA}$ and 10\% CW produced 76 (7.8 \pm 0.22 shoots/callus) and 69 (5.3 \pm 0.24 shoots/callus) percentages of shoot regenerations respectively (Table 1$)$. The optimum average of shoot length in TDZ and KIN was $8.3 \pm 0.18 \mathrm{~cm}$ and $7.4 \pm 0.14 \mathrm{~cm}$ respectively. Pugliesi et al. 


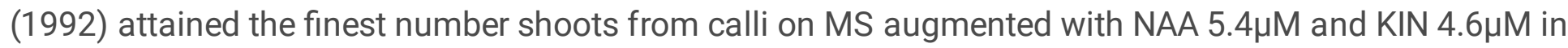
$R$. asiaticus. Based on our present and previous observations half MS medium and addition of CW to culture medium was found to be suitable for the growth of $R$. wallichianus in in vitro.

The well elongated in vitro propagated shoots (i.e. $5 \mathrm{~cm}$ ) were rooted on half strength MS medium with $2.5 \mathrm{mg} \mathrm{L}^{-1} \mathrm{IBA}+250 \mathrm{mg} \mathrm{L}^{-1}$ activated Charcoal based on our previous results (Srinivasan et al. 2021). The maximum frequency of root induction was $95 \%$ (5.1 \pm 0.19 roots per shoot with $4.2 \pm 0.21 \mathrm{~cm}$ mean root length) which was more comparable to our prior investigation (Srinivasan et al. 2021) (Fig 1g, 1h \& 2). After the successful elongation of the roots, plantlets were gradually acclimatized in the field condition. The transplantation survival rate was 94 percentages after 60 days (Fig. 1i).

Totally fifteen sets of RAPD (OPA-01 to OPA-10 \& OPC-01 to OPC-05) and ISSR (UBC-801 to UBC815) primers were screened for the genetic fidelity assessment. 9 RAPD and 8 ISSR primers produced 103 clear, unambiguous, monomorphic bands. The number of bands produced by RAPD primers were ranged from 3 (OPA-07) to 13 (OPC-01) with an average of 6 bands per primer. The average sizes of the bands were ranged from 200-1500 bp (fig 3a \& 3b). RAPD analysis showed no polymorphism in several plant species such as Prunus dulcis (Martins et al. 2004), Phoenix dactylifera (Saker et al. 2006), Jatropha curcas (Sharma et al. 2011), Thalictrum foliolosum (Mishra et al. 2020), Solanum viarum (Pandey et al. 2020), Solanum erianthum (Sarkar and Banarjee 2020), Rhododendron mucronulatum (Novikova et al. 2020) and Dendrobium fimbriatum (Tikendra et al. 2021). In ISSR markers, the banding patterns were ranged from 2 (UBC-804) to 8 (UBC-812) with an average of 5 bands per primer and size range of 2001000 bp (Fig 3c \& 3d). In modern years, ISSR markers deemed as a reliable marker to assess the genetic stability of plantlets for instance Haloxylon persicum (Kurup et al. 2018), Eucalyptus nitens (Ayala et al. 2019), Albizia lebbeck (Saeed et al. 2019), Sapium sebiferum (Hou et al. 2020), Cicer arietinum (Sadhu et al. 2020), Pterocarpus marsupium (Ahmad et al. 2020), Ficus carica (Abdolinejad et al. 2020), Rhododendron mucronulatum (Novikova et al. 2020) and Dendrobium fimbriatum (Tikendra et al. 2021). As a result, the monomorphic banding pattern produced by RAPD and ISSR markers confirms the genetic stability among the regenerants and the mother plants.

In conclusion, an efficient indirect regeneration protocol from the leaf explants of $R$. wallichianus was standardized. To the best of our knowledge, indirect organogenesis of $R$. wallichianus has not been achieved earlier. The present proposed protocol will be an effective to produce a large scale production and conservation of $R$. wallichianus. The clonal fidelity studies using RAPD and ISSR confirm all in vitro regenerated plantlets were "true to type".

\section{Abbreviations}

BA - 6-Benzyladenine

KIN - Kinetin

TDZ - Thidiazuron 
CW - Coconut Water

2,4-D - 2,4-dichlorophenoxyacetic acid

NAA - 1-Napthyl Acetic Acid

IAA - Indole-3-Acetic Acid

IBA - Indole-3-Butyric acid

DNA - Deoxyribonucleic acid

RAPD - Random Amplified polymorphic DNA

ISSR - Inter Simple Sequence Repeats

\section{Declarations}

Acknowledgements Authors are gratefully acknowledge the management of St. Joseph's college, Tiruchirappalli, India for the laboratory facilities. The authors also acknowledge the DST-SERB, New Delhi for financial support.

Author contributions PS and RT perform the study and examine the experimental data. PS prepared the manuscript. HDR gave the draw of the experimental design and edited the final version of the manuscript.

\section{Compliance with ethical standards}

Conflict of interest All Authors read, approved the manuscript and declare that they have no conflict of interest.

\section{References}

Abdolinejad R, Shekafandeh A, Jowkar A, Gharaghani A, Alemzadeh A (2020). Indirect regeneration of Ficus carica by the TCL technique and genetic fidelity evaluation of the regenerated plants using flow cytometry and ISSR. Plant Cell Tiss Organ Cult 143:131-144

Ahmad A, Anis M, Khanam MN, Alatar A (2020) Direct shoot organogenesis from shoot tip explants of a highly medicinal valued tree Pterocarpus marsupium Roxb.. In Vitro Cell.Dev.Biol.-Plant 56: 670-681.

Anu A, Babu KN, Peter KV (2004) Variations among somaclones and its seedling progeny in Capsicum annuum. Plant Cell Tiss Org Cult 76:261-267.

Ayala PG, Brugnoli EA, Luna CV, Gonzalez AM, Pezzutti R, Sansberro PA (2019) Eucalyptus nitens plant regeneration from seedling explants through direct adventitious shoot bud formation. Trees-Struct Funct 33(6):1667-1678. 
Ball ST, Zhou HP Konzak CF (1993) Influence of 2,4-D, IAA, and duration of callus induction in anther cultures of spring wheat. Plant Sci 90: 195-200.

Beruto M, Curir P, Debergh P (1996) Callus growth and somatic embryogenesis in thalamus tissue of Ranunculus asiaticus L. Cultivated in vitro: cytokinin effect and phenol metabolism. In Vitro Cell Dev Biol Plant 32:154-160.

Breiman AD, Karp RA, Shaskin H (1987) Heritable somaclonal variation in wild barley (Hordeum spontaneum). Theor Appl Genet 71:637-643.

Dorion N, Chupeau Y, Bourgin JP (1975) Isolation, culture and regeneration into plants of Ranunculus sceleratus L. leaf protoplasts. Plant Sci Lett 5:325-331 .

Doyle JJ, Doyle JL (1987) A rapid DNA isolation procedure for small quantities of fresh leaf tissue. Phytochem Bull 19:11-15.

Ebrahimi M, Mokhtari A, Amirian R (2018) A highly efficient method for somatic embryogenesis of Kelussia odorotissima Mozaff., an endangered medicinal plant. Plant Cell Tiss Organ Cult 132(1):99110.

El-Mahdy MT, Youssef M (2019) Genetic homogeneity and high shoot proliferation in banana (Musa acuminata Colla) by altering medium thiamine level and sugar type. In Vitro Cell Dev Biol 55(6):668-677.

Hammerschlag F, Garces S, Koch-Dean M, Stephanie R, Lewers K, Maas J, Smith BJ (2006) In vitro response of strawberry cultivars and regenerants to Colletotrichum acutatum. Plant Cell Tiss Org Cult 84:255-261.

Hossain Md A, Konisho K, Minami M, Nemoto K (2003) Somaclonal variation of regenerated plants in chilli pepper (Capsicum annuum L.). Euphytica 130:233-239.

Hou J, Su P, Wang D, Chen X, Zhao W, Wu L (2020) Efficient plant regeneration from in vitro leaves and petioles via shoot organogenesis in Sapium sebiferum Roxb.. Plant Cell Tiss Organ Cult 142: 143-156.

Klimek-Chodacka M, Kadluczka D, Lukasiewicz A, Malec-Pala A, Baranski R, Grzebelus E (2020) Effective callus induction and plant regeneration in callus and protoplast cultures of Nigella damascena L. Plant Cell Tiss Organ Cult 143:693-707.

Kumar KK (2004) Taxonomic and ecological studies on the shola forests of Kerala. Ph. D Dissertation. Kerala Forest Research Institute Thrissur, University of Calicut, Kerala, India.

Kurup SS, Purayil FT, Alkhaili MMS, Tawfik NH, Cheruth AJ, Kabshawi M, Subramaniam S (2018) Thidiazuron (TDZ) induced organogenesis and clonal fidelity studies in Haloxylon persicum (Bunge ex Boiss \& Buhse): an endangered desert tree species. Physiol Mol Biol Plants 24(4):683-692. 
Martins M, Sarmento D, Oliveira MM (2004) Genetic stability of micropropagated almond plantlets, as assessed by RAPD and ISSR markers. Plant Cell Rep 23(7):492-496.

Mathew KM (1999) The Flora of the Palni hills, The Rapinat Herbarium, Tiruchirapalli, India.

Mehrotra S, Khwaja O, Kukreja AK, Rahman L (2012) ISSR and RAPD based evaluation of genetic stability of encapsulated micro shoots of Glycyrrhiza glabra following 6 months of storage. Mol Biotechnol 52:262-268.

Meynet J, Duclos A (1990a) Culture in vitro de la renoncule des fleuristes (Ranunculus asiaticus L.). I. Néoformation et multiplication végétative in vitro de plantes à partir de tronçon de thalamus. Agronomie 2: $157-162$.

Meynet J, Duclos A (1990b) Culture in vitro de la renoncule des fleuristes (Ranunculus asiaticus L.). II. Production de plantes par culture d'anthères in vitro. Agronomie 10:213-218.

Miri SM (2020) Micropropagation, Callus Induction and Regeneration of Ginger (Zingiber officinale Rosc.). Open Agricult. 5: 75-84.

Mishra MK, Pandey S, Misra P, Niranjan A (2020). In vitro propagation, genetic stability and alkaloids analysis of acclimatized plantlets of Thalictrum foliolosum. Plant Cell Tiss Organ Cult 142; 441-446.

Morini S, D'Onofrio C Bellocchi G, Fisichella M (2000) Effect of 2,4-D and light quality on callus production and differentiation from in vitro cultured quince leaves. Plant Cell Tiss Organ Cult 63: 47-55.

Murashige T and Skoog F (1962) A revised medium for rapid growth and bioassays with tobacco tissue cultures. Physiol Plant 15: 473-497.

Natarajan K, Konar RN (1970). Induction of embryoids in reproductive and vegetative tissue of Ranunculus sceleratus L. in vitro. Acta Bot. Neerl.19(5):707-716.

Novikova TI, Asbaganov SV, Ambros EV, Zaytseva YG (2020) TDZ-induced axillary shoot proliferation of Rhododendron mucronulatum Turcz and assessment of clonal fidelity using DNA-based markers and flow cytometry. In Vitro Cell.Dev.Biol.-Plant 56, 307-317.

Osman NI, Sidik NJ, Awal A (2016) Effects of variations in culture media and hormonal treatments upon callus induction potential in endosperm explant of Barringtonia racemosa L. Asian Pac J Trop Biomed 6(2): 143-147.

Pandey S, Patel P, Prasad A, Sawant SV, Misra P (2020). Assessment of direct shoot organogenesis and genetic fidelity in Solanum viarum Dunal-a commercially important medicinal plant. In Vitro Cell.Dev.Biol.-Plant 56; 538-547. 
Pellegrineschi A, Brito RM, McLean S, Hoisington D (2004) Effect of 2,4-dichlorophenoxyacetic acid and $\mathrm{NaCl}$ on the establishment of callus and plant regeneration in durum and bread wheat. Plant Cell Tiss Organ Cult 77: 245-250.

Pugliesi C, Rabaglio M, Cecconi F, Baroncelli S (1992) Plant regeneration from tissue cultures of Persian buttercup (Ranunculus asiaticus L.). Plant Cell Tissue Organ Cult 28:125-128.

Sadhu S, Jogam P, Thampu RK, Abbagani S, Penna S, Peddaboina V (2020). High efficiency plant regeneration and genetic fidelity of regenerants by SCoT and ISSR markers in chickpea (Cicer arietinum L.). Plant Cell Tiss Organ Cult 141: 465-477.

Saeed T, Shahzad A, Sharma S (2019) Studies on single and double layered biocompatible encapsulation of somatic embryos in Albizia lebbeck and genetic homogeneity appraisal among synseed derived lines through ISSR markers. Plant Cell Tiss Organ Cult. 140: 431-445.

Saker MM, Adawy SS, Mohamed AA, El-Itriby HA (2006) Monitoring of cultivar identity in tissue culturederived date palms using RAPD and AFLP analysis. Biol Plant 50:198-204.

Sarkar J, Banerjee N (2020) Influence of different cytokinins on micropropagation of an important medicinal plant, Solanum erianthum D. Don, and assessment of the genetic fidelity of the regenerants. In Vitro Cell.Dev.Biol.-Plant 56; 480-490.

Sharma S, Pamidimarri DVNS, Anand KGV, Reddy MP (2011) Assessment of genetic stability in micropropagules of Jatropha curcas genotypes by RAPD and AFLP analysis. Ind Crop Prod 34:10031009.

Singh SR, Dalal S, Singh R, Dhawan AK, Kalia RK (2013) Evaluation of genetic fidelity of in vitro raised plants of Dendrocalamus asper (Shult. \& Shult. F.) Backer ex K. Heyne using DNA-based markers. Acta Physiol Plant 35:419-430.

Srinivasan P, Raja HD, Tamilvanan, R (2021) Effect of coconut water and cytokinins on rapid micropropagation of Ranunculus wallichianus Wight \& Arnn - a rare and endemic medicinal plant of the Western Ghats, India. In Vitro Cell.Dev.Biol.-Plant. https://doi.org/10.1007/s11627-020-10137-1.

Tikendra L, Potshangbam AM, Dey A, Devi TR, Sahoo MR, Nongdam P (2021) RAPD, ISSR, and SCoT markers based genetic stability assessment of micropropagated Dendrobium fimbriatum Lindl. var. oculatum Hk. f.- an important endangered orchid. Physiol Mol Biol Plants 27:341-357.

Wahyuni DK, Huda A, Faizah S, Purnobasuki H, Wardojo BPE (2020) Effects of light, sucrose concentration and repetitive subculture on callus growth and medically important production in Justicia gendarussa Burm.f. Biotechnol Rep. https://doi.org/10.1016/j.btre.2020.e00473.

Xing ZY, Yuan YH, Wang LF, Zheng LP (2010). Regenerating Plants from in vitro culture of Erigeron Breviscapus leaves. African Journal of Biotechnology 9(26): 4022-4024. 
Zheng MY, Konzak CF (1999) Effect of 2,4-dichlorophenoxyacetic acid on callus induction and plant regeneration in anther culture of wheat (Triticum aestivum L.). Plant Cell Rep 19: 69-73.

\section{Tables}

Table 1. Effect of $10 \%$ Coconut water and cytokinins on regeneration of shoots from $45 \mathrm{~d}$ old calli of $R$. wallichianus on half-strength MS medium after 6 wk.

\begin{tabular}{|c|c|c|c|c|c|c|}
\hline \multicolumn{4}{|c|}{$\begin{array}{c}\text { Growth Regulators (mg } \\
\mathrm{L}^{-1} \text { ) }\end{array}$} & \multirow[t]{2}{*}{$\begin{array}{l}\text { Percentage of } \\
\text { response }\end{array}$} & \multirow[t]{2}{*}{$\begin{array}{c}\text { Number of } \\
\text { shoots/callus }\end{array}$} & \multirow[t]{2}{*}{$\begin{array}{l}\text { Shoot length } \\
(\mathrm{cm})\end{array}$} \\
\hline$\overline{\mathrm{BA}}$ & KIN & TDZ & $\overline{\mathrm{NAA}}$ & & & \\
\hline 0.5 & - & - & 0.5 & 71 & $8.9 \pm 0.17^{\mathrm{bc}}$ & $7.0 \pm 0.13^{\mathrm{def}}$ \\
\hline 1.0 & - & - & 0.5 & 78 & $9.4 \pm 0.12^{\mathrm{abc}}$ & $7.7 \pm 0.18^{\mathrm{bcd}}$ \\
\hline 1.5 & - & - & 0.5 & 85 & $10.2 \pm 0.19^{\mathrm{ab}}$ & $8.2 \pm 0.17^{b c}$ \\
\hline 2.0 & - & - & 0.5 & 92 & $10.7 \pm 0.09^{\mathrm{ab}}$ & $8.6 \pm 0.12^{\mathrm{ab}}$ \\
\hline 2.5 & - & - & 0.5 & 97 & $11.1 \pm 0.13^{\mathrm{a}}$ & $9.2 \pm 0.21^{\mathrm{a}}$ \\
\hline 3.0 & - & - & 0.5 & 90 & $9.8 \pm 0.21^{\mathrm{abc}}$ & $8.7 \pm 0.23^{a b}$ \\
\hline- & 0.5 & - & 0.5 & 43 & $2.2 \pm 0.14^{\mathrm{i}}$ & $6.2 \pm 0.20^{g}$ \\
\hline- & 1.0 & - & 0.5 & 49 & $2.7 \pm 0.12^{\mathrm{hi}}$ & $6.5 \pm 0.19^{\mathrm{fg}}$ \\
\hline- & 1.5 & - & 0.5 & 56 & $2.5 \pm 0.18^{h i}$ & $6.3 \pm 0.11^{g}$ \\
\hline - & 2.0 & - & 0.5 & 60 & $3.7 \pm 0.22^{g h}$ & $6.6 \pm 0.14 \mathrm{f}^{\mathrm{g}}$ \\
\hline- & 2.5 & - & 0.5 & 64 & $4.4 \pm 0.27^{\mathrm{ghi}}$ & $7.0 \pm 0.23^{\mathrm{def}}$ \\
\hline- & 3.0 & - & 0.5 & 69 & $5.3 \pm 0.24^{\mathrm{fgh}}$ & $7.4 \pm 0.14^{\text {cde }}$ \\
\hline- & - & 0.5 & 0.5 & 65 & $6.8 \pm 0.16^{\mathrm{def}}$ & $7.2 \pm 0.19^{\mathrm{def}}$ \\
\hline- & - & 1.0 & 0.5 & 73 & $7.0 \pm 0.19^{\text {cde }}$ & $7.5 \pm 0.21^{\text {cde }}$ \\
\hline \multirow[t]{4}{*}{-} & - & 1.5 & 0.5 & 76 & $7.8 \pm 0.22^{\mathrm{bcd}}$ & $8.3 \pm 0.18^{b c}$ \\
\hline & & 2.0 & 0.5 & 74 & $7.1 \pm 0.25^{\text {cde }}$ & $7.9 \pm 0.11^{\mathrm{bcd}}$ \\
\hline & & 2.5 & 0.5 & 67 & $6.7 \pm 0.28^{\mathrm{def}}$ & $7.1 \pm 0.17^{\mathrm{def}}$ \\
\hline & & 3.0 & 0.5 & 62 & $6.0 \pm 0.16^{\mathrm{efg}}$ & $6.6 \pm 0.15^{\mathrm{fg}}$ \\
\hline
\end{tabular}

Values represent means \pm standard error. Means followed by the same alphabets within each column are not significantly different $(P \leq 0.05)$ according to Duncan's Multiple Range Test.

\section{Figures}



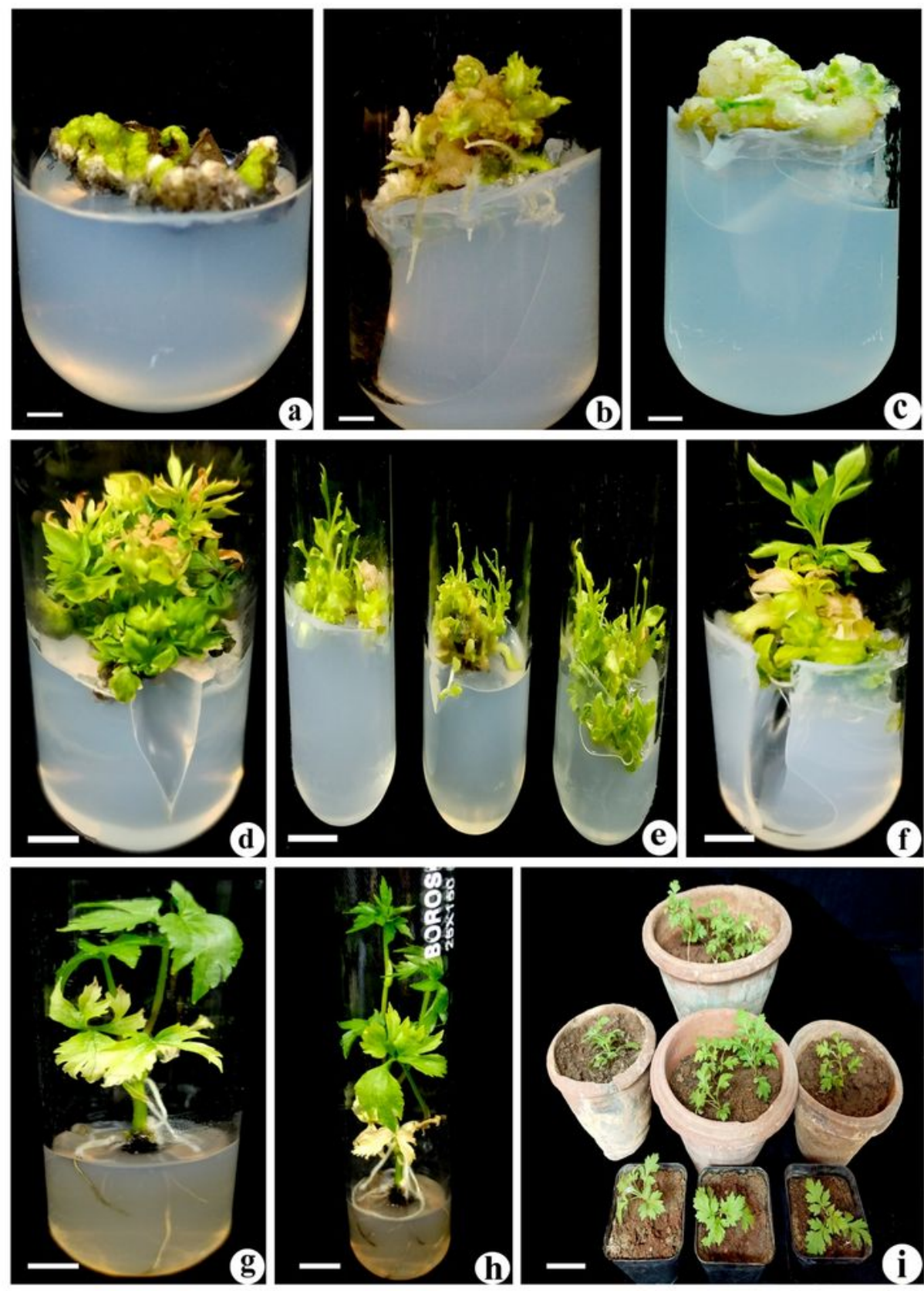

Figure 1

In vitro callus induction and shoot regeneration from leaf explants of R. wallichianus. a. Callus initiation on half-strength Murashige and skoog (MS) medium supplemented with 2,4-D 2 mg L-1 after $7 \mathrm{~d}$. b. Yellowish green, compact nodular callus induction on half-strength MS medium with 2,4-D $2 \mathrm{mg} \mathrm{L-1}$ after 6 wk. c. whitish green friable callus formation on half MS medium with $3.0 \mathrm{mg} \mathrm{L-1}$ of NAA after 6 wk. (Scale bar-5mm) d. Shoot differentiation on half-strength MS medium containing 2.5 mg L-1 BA with 0.5 
mg L-1 NAA and 10\% CW after $7 \mathrm{~d}$ of transfer (Scale bar- $5 \mathrm{~mm}$ ).e. Microshoot formation from calli after $10 \mathrm{~d}$ (Scale bar-1 $\mathrm{cm}$ ). f. Shoot elongation from calli after $20 \mathrm{~d}$ of culture (Scale bar- $5 \mathrm{~mm}$ ). g. Root initiation half-strength Murashige and Skoog (MS) medium with $2.5 \mathrm{mg} \mathrm{L-1}$ of indole-3- butyric acid and $250 \mathrm{mg} \mathrm{L}-1$ of activated charcoal after $10 \mathrm{~d}$ of transfer (Scale bar $-1 \mathrm{~cm}$ ). h. Well elongation of roots after $3 \mathrm{wk}$ (scale bar $-2 \mathrm{~cm}$ ). i. Hardened plantlet transferred to pots for survival after 2 months (scale bar $-6 \mathrm{~cm})$.
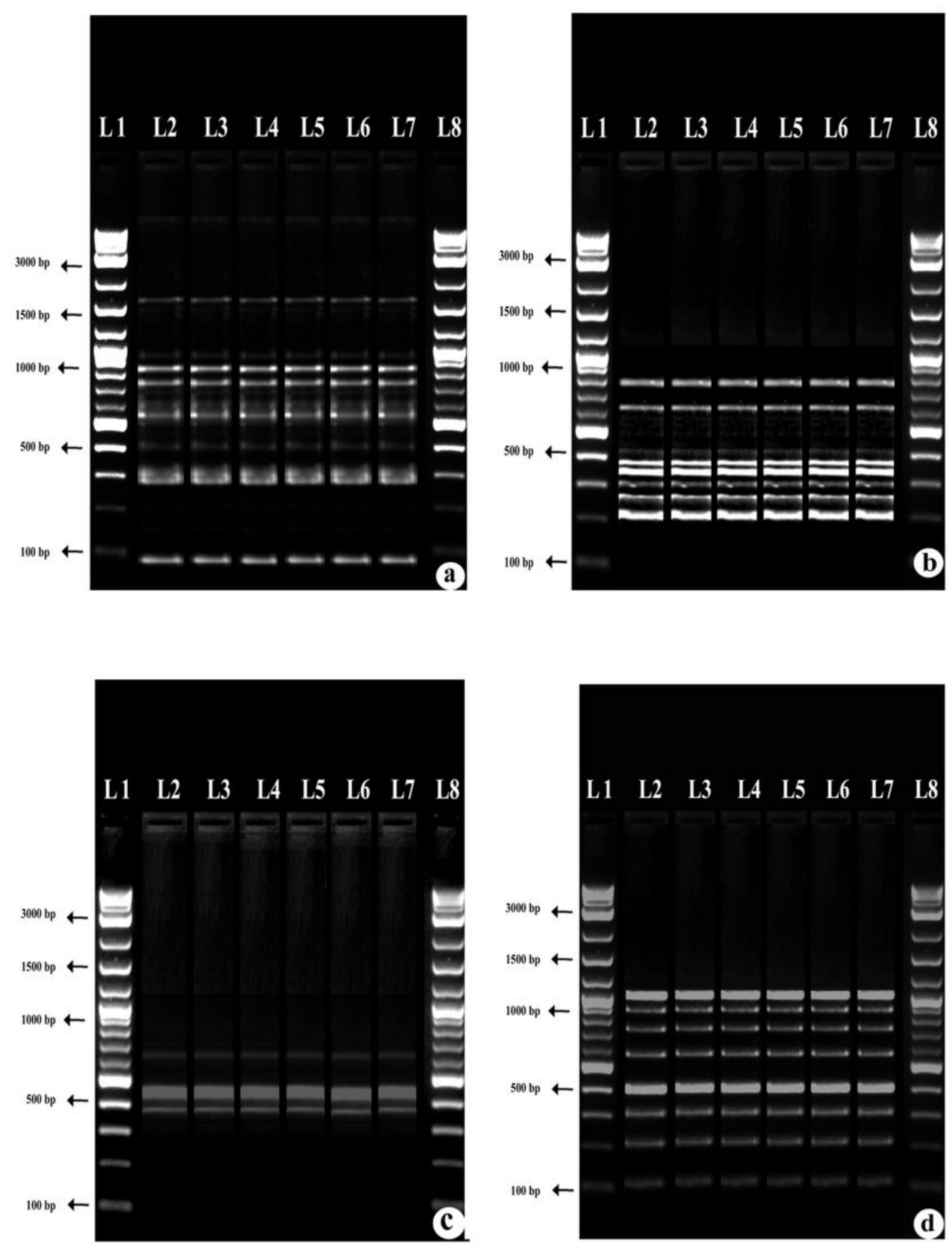

Figure 2 
Effect of half-strength Murashige and Skoog (MS) medium with various concentrations of indole-3butyric acid (IBA) and $250 \mathrm{mg} \mathrm{L}-1$ of activated charcoal on root induction from in vitro raised shoots of R. wallichianus. Columns followed by same alphabets are not significantly different at $P \leq 0.05$ according to DMRT.

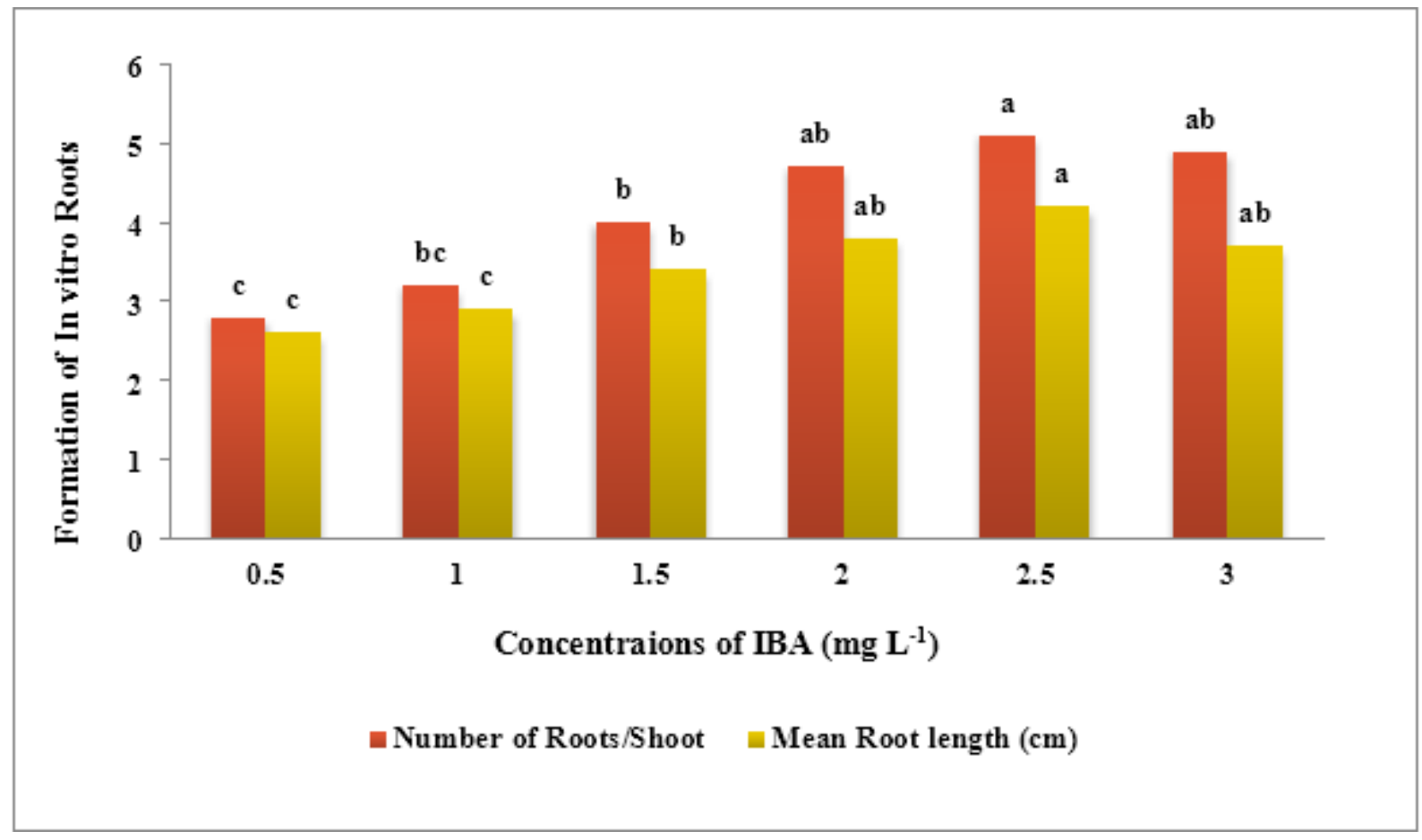

Figure 3

RAPD and ISSR profiles of mother plant and in vitro raised plantlets of R. wallichianus. Banding pattern attained from (a) OPA 1, (b) OPC 1, (c) UBC 811 and (d) UBC 812. Lane L1: 2 log DNA ladder, Lane L2: DNA banding profile of mother plant, Lane L3-L7: DNA banding profile of in vitro raised plantlets form leaf calli, L8: 2 log DNA ladder. 